\title{
The School-based Research on the Present Situation of Multimedia College English Teaching
}

\author{
${ }^{\mathrm{a}}$ Xin-hong Liu,${ }^{\mathrm{b}}$ Hai-ying Cui, ${ }^{\mathrm{c}}$ Weidong chen, ${ }^{\mathrm{d}}$ Qian-qian Chen \\ ${ }^{a, b}$ Foreign Language College Hebei Normal University of Science and Technology Qin Huang dao, China \\ ${ }^{c}$ The educational information technology dept. East China Normal University \\ ${ }^{d}$ Hebei Normal University of Science and Technology Qin Huang dao, China
}

\begin{abstract}
Multimedia college English teaching model has been used for some time in our college. Whether this model is welcomed by students is not known. This paper aims at researching the students' attitude toward this model and students' learning styles and demand on teaching. Students are not satisfied with the present multimedia teaching model. The results will arouse the consideration of college English teaching
\end{abstract}

Index Terms: mutimedia teaching; college English teaching; teaching model

(C) 2011 Published by MECS Publisher. Selection and/or peer review under responsibility of the International Conference on E-Business System and Education Technology

\section{Introduction}

Multimedia college English teaching is a typical teaching model used in our college. Teachers combine teaching courseware (including a variety of media such as text, graphics, sound, animation, and video) into their teaching. But do students like this teaching model? What do they think of teaching materials? What are their tendency of learning style? In which way do they like to communicate? This research aims at answering these questions through questionnaire.

\section{Methodology}

\subsection{Survey Instrument}

A questionnaire has a series of questions or statements to which subjects individually respond. A questionnaire can gather many discrete pieces of information about individual attributes such as attitudes, values, habits, and background characteristics including age, education, and income (as cited in Seon-hwa Eun, 2001).

A questionnaire was designed to survey some problems and students' attitude toward the current model of college English and students learning styles in our college. The statements in this questionnaire were based on

Corresponding author:

E-mail address: ${ }^{\mathrm{a}}$ Liuxinhong75@163.com, ${ }^{\mathrm{b}}$ wyx_chy@126.com, ${ }^{\mathrm{c}}$ wdchsz@sina.com, ${ }^{\mathrm{d}}$ chenqianqian81@yahoo.com.cn 
five-point Likert scale:

1. This statement is completely not or hardly completely suitable for me.

2. This statement is generally not suitable for me.

3. This statement is sometimes suitable for me.

4. This statement is generally suitable for me.

5. This statement is completely or almost completely suitable for me.

The statements fell into four major threads of investigation. Section one consisted of six statements regarding the students' perceptions of teaching materials. Section two consisted of 12 statements dealing with students learning style. Section three consisted of seven statements related to students' perceptions about present teaching model. Section four consisted of four statements regarding students' tendency to communicate.

The questionnaire was written in Chinese in order to avoid misunderstanding. After the survey, they were translated into English for the analysis.

\subsection{Data Collection Procedures}

The questionnaire was delivered in person to students at class in the sample, with a request that it should be completed and handed in at once.

In order to increase the effectiveness of survey questionnaires, the researcher conducted the questionnaire at class when teachers finished their teaching on Sep.23rd, 2009. Since students were very serious about filling in the questionnaires, all these were effective.

\subsection{Data Analysis}

Descriptive statistics like frequency, percentage, central tendency (mean) and variability (standard deviation) were used for data analysis through SPSS13.0 Version for Windows. Those responses were numerically coded and interpreted based on the mean scores of each items. The data analysis was divided into three steps-item analysis, reliability check, and descriptive analysis.

\section{1) Item analysis.}

Data collected from Likert type questionnaire needs to be sorted out the inappropriate statements through item analysis. Item analysis is that the total scores of each subject is descended, one quarter of the high-scored subjects are regarded as high-scored group, one quarter of low-scored subjects are regarded as low-scored group, then compare the difference of mean in each statement between high-scored group and low-scored group. If the difference in a statement can't reach the obvious level $(\mathrm{a}<0.05$ or $\mathrm{a}<0.01)$, the statement has no difference in different subjects and should be omitted in analysis (Qin Xiaoqing, 2003).

\section{2) Reliability check.}

After the item analysis was completed, the reliability of the instrument was tested. In general, reliability problems occur when the quality of an instrument is so poor (e.g., vague instructions, open to interpretations, interviewer errors. etc.) that performance on the instrument can be affected by outside influences. Absence of this error is the extent to which an instrument is consistent in measuring whatever it measures. To assess the reliability of instrument statistically, Cronbach's Alpha was used to test an internal consistency of the domain of the instrument, since items were summated and added together to represent each variable by using Likert scale.

\section{3) Descriptive analysis.}

The Likert type responses in Part Two were analyzed through descriptive statistics, such as mean, standard deviation and rank. The total four sections represented four domains and all statements under each domain were summated. Negative statements in each section were reversed for summation when entering data. The central tendency (mean), variability (SD and Rank) of mean scores were presented for data analysis. The higher summated scores indicated the more positive perceptions of students about each statement. 


\section{Discussion and Results}

This part presents findings from statistical analyses of the data collected from the survey questionnaires. For the survey data analysis, descriptive statistics are used. And the researcher will examine the findings in relation to the specific characters .

\section{1 Students' Perception of the Present Teaching}

"I hope teachers can often change their teaching method" got the highest mean score 4.63, which implied that students felt that English courses were dull or at least couldn't motivate them. "I'm satisfied with the present teaching method (mean

score of 3.60)" and "I don't like attending English course because of its dullness (mean score of 3.50)" seems to be contrary, but this shows that students were careless about the English class, which may be because they had no right to choose what they wanted to learn and didn't know what they needed to learn.

Students still felt that the present teaching helped to improve their listening and speaking. The results mentioned above displayed that students seldom participated in class oral activities and communication with others in English. But why did they agree that the present teaching helped to improve their listening and speaking? The only explanation was that the online courseware worked. Self-study in computer lab fostered students self control. (see TABLE I .)

TABLE I.

\begin{tabular}{cccc}
\hline \hline Questions & Mean & $\begin{array}{c}\text { Std. } \\
\text { Deviatio } \\
\boldsymbol{n}\end{array}$ & Rank \\
\hline $\begin{array}{c}\text { 22.I hope teachers can often change } \\
\text { their teaching method. }\end{array}$ & 4.63 & .82 & 1 \\
$\begin{array}{c}\text { 16. I'm satisfied with the present } \\
\quad \text { teaching method. }\end{array}$ & 3.60 & .81 & 2 \\
$\begin{array}{c}\text { 25.The present teaching helps } \\
\text { improve my listening and speaking. } \\
\text { 24.I don't like attending English } \\
\text { course because of its dullness. }\end{array}$ & 3.56 & .83 & 3 \\
$\begin{array}{c}\text { 13. I can manage myself better than } \\
\text { before after I study English at the } \\
\text { computer lab. }\end{array}$ & 3.07 & 1.02 & 4 \\
\hline
\end{tabular}

\section{2 Students' Perception of Teaching and Learning Materials}

Most students agreed that the content of the courseware was rich and interesting (mean score of 3.86) and so is the content of textbooks (mean score of 3.53). Still students agreed that the use of the courseware 
in this course made it more interesting. Students also agreed that they still learned English besides textbooks. But students disagree that they spent more time practicing English because of the use of courseware (mean score of 2.77) and learning more English because of courseware (mean score of 2.55). All these showed that even interesting materials might fail to motivate students to study and meet the objective. So teaching model and instructional design is the key to making the materials functional. (see TABLE II.)

TABLE II.

\begin{tabular}{cccc}
\hline \hline Questions & Mean & $\begin{array}{c}\text { Std. } \\
\text { Deviation }\end{array}$ & Rank \\
\hline $\begin{array}{c}\text { 2. The content of the } \\
\text { courseware is rich and } \\
\text { interesting. }\end{array}$ & 3.84 & .86 & 1 \\
$\begin{array}{l}\text { 28. I'm interested in the } \\
\text { content of the textbooks. } \\
\text { 15. The use of the }\end{array}$ & 3.53 & .95 & 2 \\
$\begin{array}{c}\text { courseware in this course } \\
\text { made it more interesting. } \\
\text { 30. I learn English } \\
\text { sometimes from other } \\
\text { English materials. }\end{array}$ & 3.48 & .92 & 3 \\
$\begin{array}{l}\text { 4. I spent more time } \\
\text { practicing English because } \\
\text { of the use of the }\end{array}$ & 2.77 & .91 & 4 \\
$\begin{array}{c}\text { courseware in this course. } \\
\text { 3. I learned more English } \\
\text { because of using the } \\
\text { courseware. }\end{array}$ & 2.55 & .86 & 5 \\
\hline
\end{tabular}

\section{3 The Tendency of Learning Style}

Students almost agreed that talking with classmates in English could improve their oral English (mean score of 3.78). Students were more likely to study by themselves (mean score of 3.69) than through cooperation with their classmates (mean score of 3.25), but this till showed that they could accept both way of learning. "I sometimes surf the English sites in order to learn English" got the mean score of 3.16, which indicated that some students had the willingness to study independently and look for materials. "I dare not speak English at class" (mean score of 3.22) and "I'd like to answer teachers' questions at class," (mean score of 2.99) suggested that students' class participation was very poor. The result of the total of questions implied that learning styles of students were diversified. They didn't like to participate in class activities, but they could accept the concept of cooperative learning. (see TABLE III.)

\section{4 The Tendency of Communicating Style}

Students didn't like to ask teachers questions privately (mean score of 2.88); nor did they like to ask teachers questions in class (mean score of 2.84). Even through BBS and E-mail they still didn't like to solve problems and communicate with teachers and classmates. Students seldom communicated with classmates and chatted with foreign net pals in English. All these demonstrated that students didn't like to communicate with teachers in any way. Even though they had the tendency to cooperate with classmates, they were willing to solve them by 
themselves or just left them there when they met problems. In addition, students didn't like to use English to communicate with others, although they spent a lot of time in chatting on line. The lack of interaction and unwillingness to communicate with others in English would lead to the low level of communicative competence. (see TABLE IV.)

TABLE III.

\begin{tabular}{lccc}
\hline \hline Questions & Mean & $\begin{array}{c}\text { Std. } \\
\text { Deviation }\end{array}$ & Rank \\
\hline $\begin{array}{c}\text { 19. Talking with classmates } \\
\text { in English can improve my } \\
\text { oral English. }\end{array}$ & 3.78 & .82 & 1 \\
$\begin{array}{c}\text { 1. I like studying by myself } \\
\text { through using the } \\
\text { multimedia courseware on } \\
\text { the campus web. }\end{array}$ & 3.69 & .96 & 2 \\
$\begin{array}{c}\text { 17. I'd like to learn English } \\
\text { by myself. }\end{array}$ & 3.40 & .88 & 3 \\
$\begin{array}{l}\text { 18. I'd like to learn English } \\
\text { through cooperation with } \\
\text { my classmates. }\end{array}$ & 3.25 & .94 & 4 \\
$\begin{array}{c}\text { 8. I dare not speak English } \\
\text { at class. }\end{array}$ & 3.22 & 1.08 & 5 \\
$\begin{array}{l}\text { 20. I sometimes surf the } \\
\text { English sites in order to } \\
\text { learn English. }\end{array}$ & 3.16 & .98 & 6 \\
$\begin{array}{l}\text { 7. I'd like to answer } \\
\text { teachers' questions at class. }\end{array}$ & 2.99 & .98 & 7 \\
\hline
\end{tabular}

TABLE IV.

\begin{tabular}{|c|c|c|c|}
\hline Questions & Mean & $\begin{array}{c}\text { Std. } \\
\text { Deviati }\end{array}$ & $\begin{array}{c}\operatorname{Ran} \\
k\end{array}$ \\
\hline $\begin{array}{l}\text { 12. I would like to ask teachers questions } \\
\text { privately. }\end{array}$ & 2.88 & .89 & 1 \\
\hline $\begin{array}{l}\text { 11. I would like to ask teachers questions } \\
\text { at class. }\end{array}$ & 2.84 & .98 & 2 \\
\hline $\begin{array}{l}\text { 6. I often communicate with my } \\
\text { classmates in English. }\end{array}$ & 2.67 & .98 & 3 \\
\hline $\begin{array}{l}\text { 10. I would like to solve study problems in } \\
\text { English through e-mail or BBS. }\end{array}$ & 2.38 & .86 & 4 \\
\hline $\begin{array}{l}\text { 9. I would like to communicate with } \\
\text { teachers and classmates through e-mail or } \\
\text { BBS. }\end{array}$ & 2.22 & .75 & 5 \\
\hline $\begin{array}{l}\text { 21. I sometimes chat with foreign net pals } \\
\text { in English. }\end{array}$ & 2.10 & .82 & 6 \\
\hline
\end{tabular}




\section{Conclusion}

Students gave high evaluation on courseware, but they didn't think their English was improved through the use of courseware. The researcher thinks that although the courseware can improve the interestingness of teaching and learning, the instructional value of the courseware may be poor. Some published courseware in fact are the copy of textbook decorated by some pictures and sound but lack of interaction and flexibility. So teaching and learning language shouldn't depend on courseware too much.

Teachers thought the content of textbook was not interesting but students' opinion was opposite, which implied that teaching materials shouldn't be decided only by teachers.

Teachers often adopted teaching methods such as text explanation and group discussion. Students gave positive evaluation on teaching method, but they still hoped that teachers could often change their teaching model. This shows that students have high demand on teaching. The diversified teaching methods not only avoid dullness but also meet the needs of students.

Since multimedia technology allow a variety of media (text, graphics, sound, animation, and video) to be accessed on a single machine, it can add more interest, more information into English class. But how to make instructional design and how to make effective use of multimedia is still a question to research.

\section{References}

[1] Seon-hwa Eun,“ Contextual Autonomy in EFL Classrooms: A Critical Review of English Teaching Methods in South Korea (Master dissertation, The Ohio State University)", Proquest Information and Learning (UMI Microform 3031198), 2001

[2] Qin xiaoqing, Quantitative Analysis in Foreign Language Teaching.Wuhan: Huazhong University of Science \& Technology Press , 2003 (in Chinese).

[3] Xu, Fang , \& Warschauer, M., "Technology and curricular reform in China: A case study",. TESOL Quarterly 38(2), pp. 301-323, 2004 (references).

[4] Richard P. Taylor ,\& Christina Gitsaki., “Teaching WELL in a Computerless Classroom?”, Computer Assisted Language Learning (16) 4, pp. 275-294, 2003 (references). 